\title{
A new species of Aplectana (Nematoda: Cosmocercidae) parasite of Pleurodema nebulosum (Anura: Leptodactylidae) from the Monte desert, Argentina, with a key to Neotropical species of the genus Aplectana
}

\author{
MAURICIO D. PIÑEIRO GOMEZ ${ }^{1}$, CYNTHYA E. GONZÁLEZ ${ }^{2,4} \&$ EDUARDO A. SANABRIA ${ }^{3,4}$ \\ ${ }^{l}$ Facultad de Ciencias Exactas, Físicas y Naturales, Universidad Nacional de San Juan. Av. Ignacio de la Roza 590 (O), Rivadavia, \\ San Juan, Argentina, C.P. 5400. E-mail: mauridpg@gmail.com \\ ${ }^{2}$ Centro de Ecología Aplicada del Litoral, Ruta Provincial Número 5, km 2,5, Corrientes, Argentina, C.P. 3400. \\ E-mail: cynthyaelizabethg@hotmail.com \\ ${ }^{3}$ Instituto de Ciencias Básicas, Facultad de Filosofia Humanidades y Artes, Universidad Nacional de San Juan. Av. José Ignacio de la \\ Roza 230 (O), Capital, San Juan, Argentina C.P. 5400. E-mail: sanabria.eduardoa@gmail.com \\ ${ }^{4}$ Consejo Nacional de Investigaciones Científicas y Técnicas
}

\begin{abstract}
Here we describe a new cosmocercid nematode, Aplectana nebulosa sp. nov., from the small and large intestines of Pleurodema nebulosum (Anura: Leptodactylidae), from the Monte desert of San Juan, Argentina. The new species belongs to the Aplectana group that possesses a gubernaculum and unpaired adcloacal papilla anteriorly to cloaca. It resembles $A$. membranosa, A. paraelenae and A. travassosi by the presence of four adcloacal papillae, but differs from those species by the following characters: number and arrangement of precloacal papillae; number and arrangement of postcloacal papillae; shape and size of spicules and gubernaculum, and by the presence of lateral alae in caudal region of males. The description of the new species is based on light microscopy and scanning electron microscopy (SEM) and we also provide a key to Neotropical species of Aplectana.
\end{abstract}

Key words: Nematode parasite, Amphibians, San Juan Province, Argentina

\section{Introduction}

The frog genus Pleurodema Tschudi (Leiuperinae) includes 13 valid species widely distributed from Panama to southern South America (Frost 2016), nine of which are present in Argentina (Ferraro and Casagranda, 2009). Pleurodema nebulosum and Pleurodema guayapae are the species that constitute the P. nebulosum clade (Faivovich et al., 2012), and within this clade, Pleurodema guayapae inhabits the 'Chaco Seco' ecoregion in Argentina, while P. nebulosum occurs in the ecoregions 'Chaco Seco', 'Monte de Sierras and Bolsones', 'Monte de Llanuras and Mesetas', and 'Espinal' and its distributional limits reach the 'Pampa', 'Puna', and 'Estepa' regions. In Argentina, $P$. nebulosum is the species of this genus with widest altitude range (Ferraro and Casagranda, 2009), and is a common frog in the Monte desert.

The information available on metazoan parasites of the herpetofauna from the Monte desert in Argentina mostly refers to helminth species found in reptiles (Ramallo and Díaz, 1998; Ramallo et al., 2002a; 2002b; 2016a; 2017; Goldberg et al., 2004). Regarding helminths found in amphibians, González et al. (2013a) described the nematode Falcaustra sanjuanensis González, Sanabria and Quiroga, 2013 from the large intestine of Odontophrynus cf. barrioi and González et al. (2013b) reported the nematode Aplectana hylambatis (Baylis, 1927) Travassos, 1931 from the large intestine of Rhinella arenarum Hensel, 1867. González et al. (2014) reported the presence of the nematodes F. sanjuanensis and Contracaecum sp. (larvae), from the large intestine and stomach of Lithobates catesbeianus (Shaw, 1802). Finally, F. sanjuanensis was also reported by Ramallo et al. (2016b) from Leptodactylus latrans (Steffen, 1815).

However, no helminths have been described for Pleurodema nebulosum from Argentina until now. Thus, here 
we describe a new cosmocercid species belonging to the genus Aplectana Railliet and Henry, 1916. This species was found as parasites of the digestive tract of P. nebulosum from Matagusanos, Ullúm Department, San Juan province. We also provide a key of identification for the Aplectana species found in the Neotropical Realm.

\section{Materials and methods}

Study area: The Matagusanos barreal is located $55 \mathrm{~km}$ east of San Juan city, in Ullúm Department (31.11250 S, $68.63587 \mathrm{~W}$, elevation: $600 \mathrm{~m}$ ). The dominant vegetation in the area includes Larrea cuneifolia and Larrea divaricata (jarillas), Prosopis sp. (algarrobos), and Capparis atamisquea (matagusanos). This region is part of the Monte desert, characterized by its arid climate with a mean annual temperature of $17.3^{\circ} \mathrm{C}$, a mean maximum temperature of $25.7^{\circ} \mathrm{C}$, and a mean minimum temperature of $10.4^{\circ} \mathrm{C}$, with a mean annual rainfall of $89 \mathrm{~mm}$ during the summer months (wet season) (Cabrera, 1976; Warner, 2004). In this area we collected by hand 41 specimens of Pleurodema nebulosum (18 females, 23 males) during the breeding season (January 2012).

Analytical procedure: The frogs were examined for nematode parasites using the standard technique. Intestinal nematodes were fixed in $10 \%$ formaldehyde solution and preserved in $70 \%$ ethanol and cleared with lactophenol for examination under the light microscope. Illustrations were made using a Leica microscope with the aid of a drawing tube. For examination with scanning electron microscope (SEM), the nematodes were postfixed in $1 \% \mathrm{OsO}_{4}$, dehydrated through an ethanol and an acetone series and critical point dried. The specimens were coated with gold and examined with a JSM-5800 scanning electron microscope. The measurements along the text are given in micrometers unless otherwise indicated, and are presented as the mean \pm 1 Standard Deviation with the range in parentheses; measurements of holotype and allotype are shown in brackets. Amphibian taxonomy follows Frost (2016). Nematodes were deposited in the Helminthological Collection of Museo de La Plata, La Plata, Argentina, and the Helminthological Collection of Centro de Ecología Aplicada del Litoral, Corrientes, Argentina. Symbiotypes are stored in the Herpetological Collection of Fundación Miguel Lillo.

\section{Results}

Aplectana nebulosa sp. nov.

(Figs. 1-2)

General morphology. Small, slender nematodes. Cuticle transversely striated. Slight sexual dimorphism, females larger than males (Fig. 1A, B). Narrow lateral alae present in both sexes, beginning at region of nerve ring and ending at the middle of tail in females and at level of first pair of precloacal papillae in males (Figs. 1E-1K). Numerous small somatic papillae present. Mouth with three lips; dorsal lip with two cephalic papillae and each ventrolateral lip with one cephalic papilla and one large amphid (Fig. 1C). Excretory pore anterior of oesophageal bulb (Fig. 1D).

Male (based on holotype and 15 paratypes): Total length $2.9 \pm 0.41 \mathrm{~mm}(2.2-3.5 \mathrm{~mm})$ [2.9 mm]; maximum width $136.5 \pm 25.4$ (100-178) [125]. Pharynx length $40.7 \pm 4.2$ (35-49.5) [46], width $34.3 \pm 5.1$ (25-41) [37.7]; oesophagus: corpus length $320.2 \pm 31.4(280-392)$ [310] width $34.8 \pm 5.3(25-40)$ [25]; isthmus length $43.7 \pm 8.4$ (30-56.5) [30], isthmus width $23.8 \pm 5.1(18-35.5)$ [25]; bulb length $54.2 \pm 9$ (35.5-68) [60], bulb width $53.3 \pm 5.8$ (39-61) [55]. Nerve ring $223.0 \pm 23.4(175-255)$ [240] and excretory pore $331.7 \pm 72.9(191-502.5)$ [345], from anterior extremity, respectively. Tail length $167.9 \pm 31.3(105-220)$ [202.2]. Cloacal papillae arranged as follows (Fig. 1E, F): Two rows of 6-7 pairs of precloacal papillae, the last two paris located laterally to the cloaca (Fig. 2A); 2 pairs of adcloacal papillae in anterior margin of cloaca and one middle, large unpaired papilla between the two anterior pairs (Fig. 2B); 5 pairs of postcloacal papillae (first and second pairs ventral, third pair lateral, fourth pair ventral, fifth pair lateral) (Fig. 2C); papillae pattern: 6-7:2:5+1. Spicules slightly equal, length $104.2 \pm 12.4$ (85-125.9) [110], pointed at distal end and with variably shaped capitulum (Fig. 1G). Gubernaculum length $52.2 \pm$ 9.1 (37.4-62.9) [55], weakly sclerotized, ovate in ventral view (Fig. 1H).

Female (based on allotype and 13 paratypes): Total length $4.6 \pm 0.28 \mathrm{~mm}(2.9-5.8 \mathrm{~mm})$ [4.54 mm]; maximum width $200 \pm 60.1$ (100-298) [235]. Pharynx length $58.2 \pm 15$ (30-83) [70], pharynx width $49.2 \pm 12.5$ (28-72) [60]; 


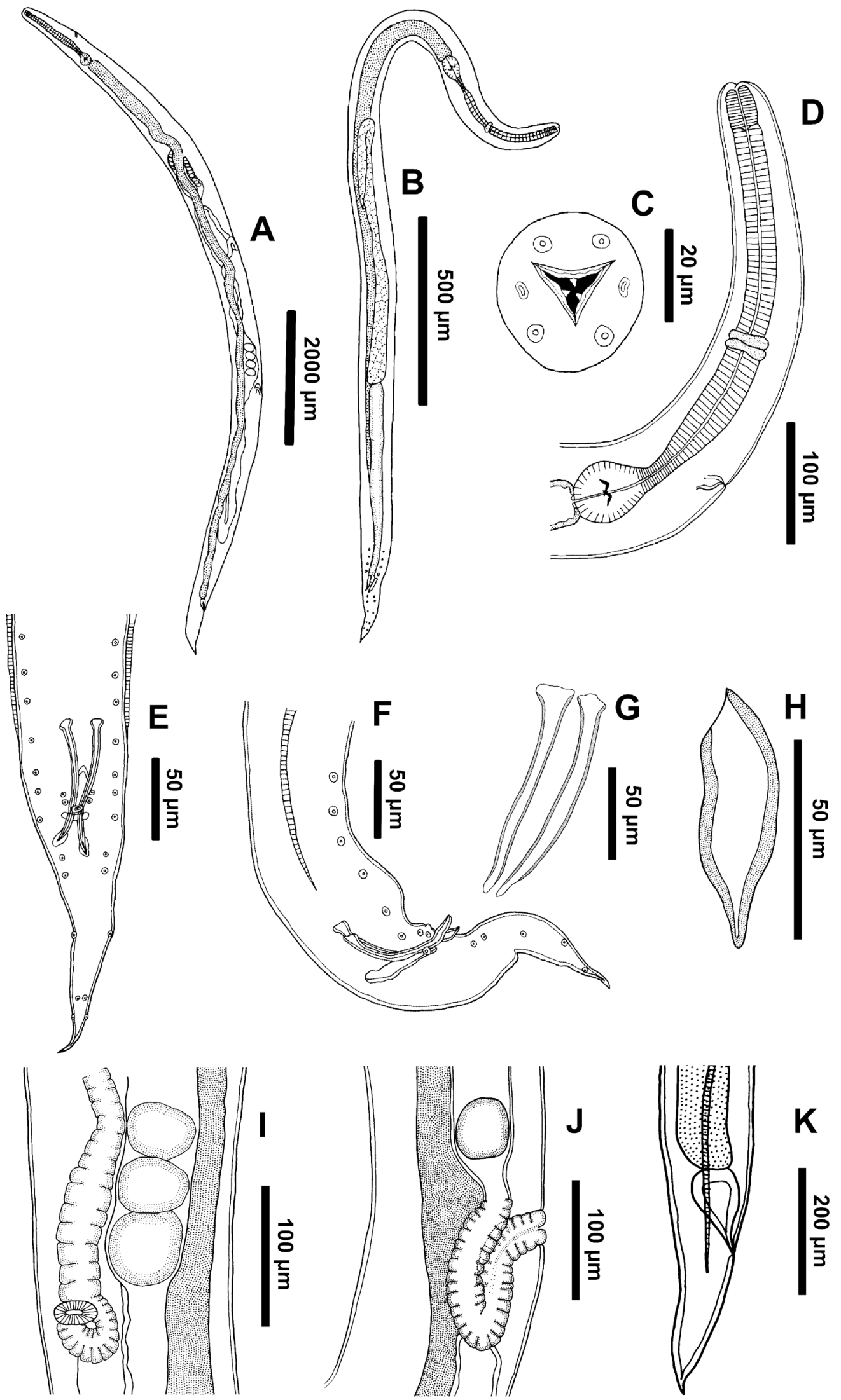

FIGURE 1. Aplectana nebulosa sp. nov. from P. nebulosum. A. Female, general view. B. Male, General view. C. Male, anterior extremity, apical view. D. Male, anterior extremity, lateral view. E. Male, posterior extremity, ventral view. F. Male, posterior extremity, lateral view. G. Spicule, ventral view. H. Gubernaculum, ventral view. I. Female, vulva and ovejector, ventral view. J. Female, vulva and ovejector, lateral view. K. Female, posterior extremity, lateral view. 

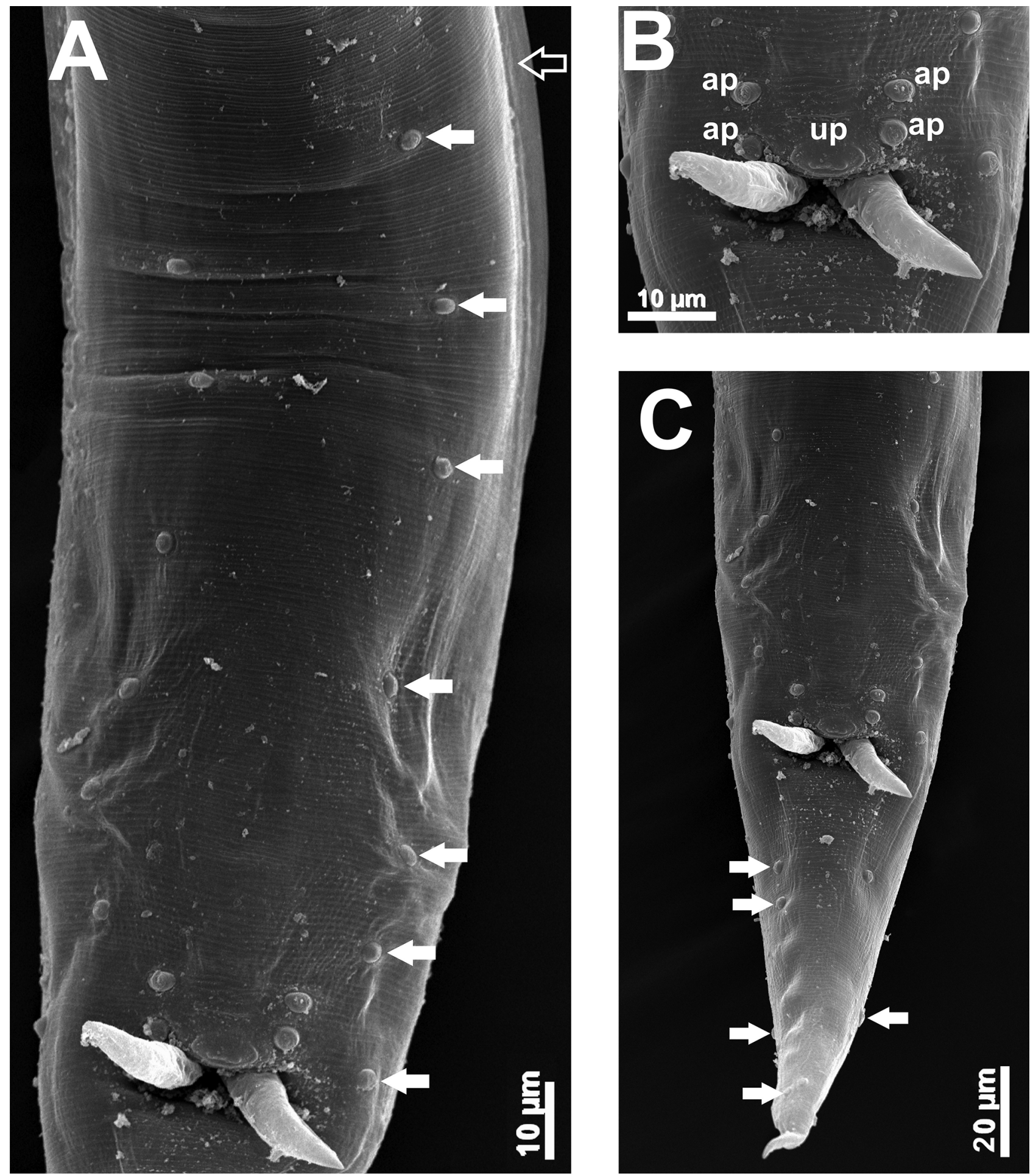

FIGURE 2. Aplectana nebulosa sp. nov. from P. nebulosum. A. Posterior end of male, detail of precloacal papillae. B. Posterior end of male, detail of adcloacal papillae and spicules. C. Posterior end of male, detail of postcloacal papillae. Abbreviations: ap: adcloacal papillae; up: unpaired papilla. In figure A, closed arrows indicate precloacal papillae; open arrows indicate lateral alae; in figure $\mathrm{C}$, closed arrows indicate postcloacal papillae.

oesophagus: corpus length $395.4 \pm 65.0$ (277-485) [425], width $47.6 \pm 13.2$ (30-79.1) [60]; isthmus length $48.5 \pm$ 5.3 (41-58) [50], isthmus width $29.5 \pm 4.7$ (21-38) [40], bulb length $68.4 \pm 9.8$ (52-84) [80], bulb width $62.9 \pm 9.4$ (48-75) [70]. Nerve ring $249.4 \pm 40.3$ (200-325) [285] and excretory pore $417.7 \pm 70$ (234-506) [450] from anterior extremity, respectively. Vulva post-equatorial, transverse slit, slightly salient, situated $1.7 \pm 0.43 \mathrm{~mm}(1.0-$ 2.5) $[1.40 \mathrm{~mm}]$ from posterior extremity; muscular ovejector, directed anteriorly (Fig. 1I, J), joining 2 uteri, 1 
directed anteriorly, 1 posteriorly. Tail, conical, $261.7 \pm 41.1$ (200-343) [215] in length (Fig. 1K). Eggs, unembryonated, thin shelled oval, length $84.8 \pm 15.0$ (61.5-105) [90], width $67 \pm 14.2$ (49-90) [80].

\section{Taxonomy summary}

Site of infection: small and large intestine.

Type locality: Matagusanos, Ullúm Department, San Juan Province, Argentina (Fig. 3B).

Deposition of types: Holotype (male), allotype (female) and paratypes ( 2 males, 2 females) in Helminthological Collection of the Museum of La Plata (Holotype: MLP-He 7156; Allotype: MLP-He 7157; Paratypes: MLP-He 7158); Paratypes (5 males, 5 females) in Helminthological Collection of Centro de Ecología Aplicada del Litoral (CECOAL 16062601).

Symbiotype: Pleurodema nebulosum (Burmeister, 1861) (Anura, Leptodactylidae) (Fig. 3A), Herpetology Collection of Fundación Miguel Lillo (Deposited number FML 29422 to 29433).

Etymology. The new species is named in reference to its host.

Host-parasite data. Prevalence $58.5 \%$, twenty-four of the frogs were found to harbour 397 nematodes.

Remarks. The genus Aplectana is characterized by possessing lateral alae and somatic papillae, males without rosettes or plectanes on the posterior end, and females with numerous thin-shelled eggs in the uteri, and 2 ovaries anterior to the vulva (Gibbons, 2010). Nematodes of this genus parasitize mainly amphibians and some species of reptiles worldwide (Baker, 1987).

The species of genus Aplectana are grouped mainly according to the presence and absence of gubernaculum; other features that distinguish these helminths are the number and arrangement of caudal papillae, and the size of the gubernaculum and spicules.

According to Bursey et al. (2011), there are 26 species reported for the Neotropical Realm, 19 of them with gubernaculum: A adaechevarriae Ramallo, Bursey and Goldberg, 2008, A. albae Adamson and Baccam, 1988, $A$. elenae Baker and Vaucher, 1986, A. hamatospicula Walton, 1940, A. herediaensis Bursey, Goldberg and Telford, 2006, A. hylambatis (Baylis, 1927) Travassos, 1931, A. incerta Caballero, 1949, A. itzocanensis Bravo Hollis, 1943, A. lopesi Silva, 1955, A. membranosa (Schneider, 1866) Miranda, 1924, A. mexicana (Caballero, 1933) Ballesteros-Marquez, 1945, A. micropenis Travassos, 1925, A. paraelenae Baker and Vaucher, 1986, A. pusilla Miranda 1924, A. raillieti Travassos, 1925, A. ryšavýi Barus and Coy Otero, 1969, A. travassosi (Gomes and Motta, 1967) Baker, 1980, A. tucumanensis Ramallo, Bursey and Goldberg, 2008, and A. vellardi Travassos, 1926.

Apart from this, two groups can be identified, following the characteristics of caudal papillae: those with a large unpaired papilla anterior to the cloaca, and those without this character. Of the above mentioned species with gubernaculum, eleven have an unpaired papilla: A. albae, A. elenae, A. hamatospicula, A. hylambatis, A. itzocanensis, A. membranosa, A. paraelenae, A. raillieti, A. ryšavýi, A. travassosi, and A. vellardi.

The new species described here belongs to the group of species that possess both a gubernaculum and an unpaired papilla anterior to the cloaca, being more related to A. membranosa, A. paraelaenae and A. travassosi for possessing four adcloacal papillae, pre-oesophageal excretory pore, males with tail tapering gradually to spike-like distal portion, and gubernaculum elongated, with posterior end pointed and thickened borders.

However, the new species differs from $A$. membranosa by the following characters: 1) number of precloacal papillae (6-7 pairs vs. 3 pairs); 2) number and arrangement of postcloacal papillae ( $1^{\circ}$ and $2^{\circ}$ ventral, $3^{\circ}$ lateral, $4^{\circ}$ ventral, $5^{\circ}$ lateral vs. $1^{\circ}$ and $2^{\circ}$ ventral, $3^{\circ}$ lateral, $4^{\circ}$ ventral); 3 ) shape and size of spicules (no forked spicules, 85 $125.9 \mu \mathrm{m}$ vs. forked spicules, $227-234.3 \mu \mathrm{m})$.

Aplectana nebulosa sp. nov. can also be distinguished from A. paraelenae by the following characters: 1 ) number of precloacal papillae (6-7 pairs vs. 3 pairs, respectively); 2 ) number and arrangement of postcloacal papillae $\left(1^{\circ}\right.$ and $2^{\circ}$ ventral, $3^{\circ}$ lateral, $4^{\circ}$ ventral, $5^{\circ}$ lateral vs. $1^{\circ}, 2^{\circ}, 3^{\circ}$ subventral, $4^{\circ}$ and $5^{\circ}$ subdorsal, $6^{\circ}$ lateral $) ; 3$ ) size of spicules (85-125.9 $\mu \mathrm{m}$ vs. $227 \mu \mathrm{m}$ ); 4) position of end of lateral alae in males (precloacal, at the level of $3^{\circ}$ pair of precloacal papillae vs. postcloacal, at middle of tail).

Finally, Aplectana nebulosa sp. nov. differs from A. travassosi by the following characters: 1) number of precloacal papillae (6-7 pairs vs. 3 pairs); 2 ) number and arrangement of postcloacal papillae $\left(1^{\circ}\right.$ and $2^{\circ}$ ventral, $3^{\circ}$ lateral, $4^{\circ}$ ventral, $5^{\circ}$ lateral vs. $1^{\circ}$ pair ventral, $2^{\circ}, 3^{\circ}$ and $4^{\circ}$ subventral); 3 ) size of spicules ( $85-125.9 \mu \mathrm{m}$ vs. 230

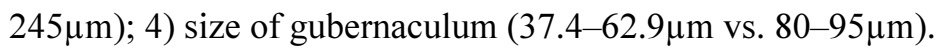

We provide a key for the species of Aplectana from amphibians and reptiles from Neotropical Realm. 


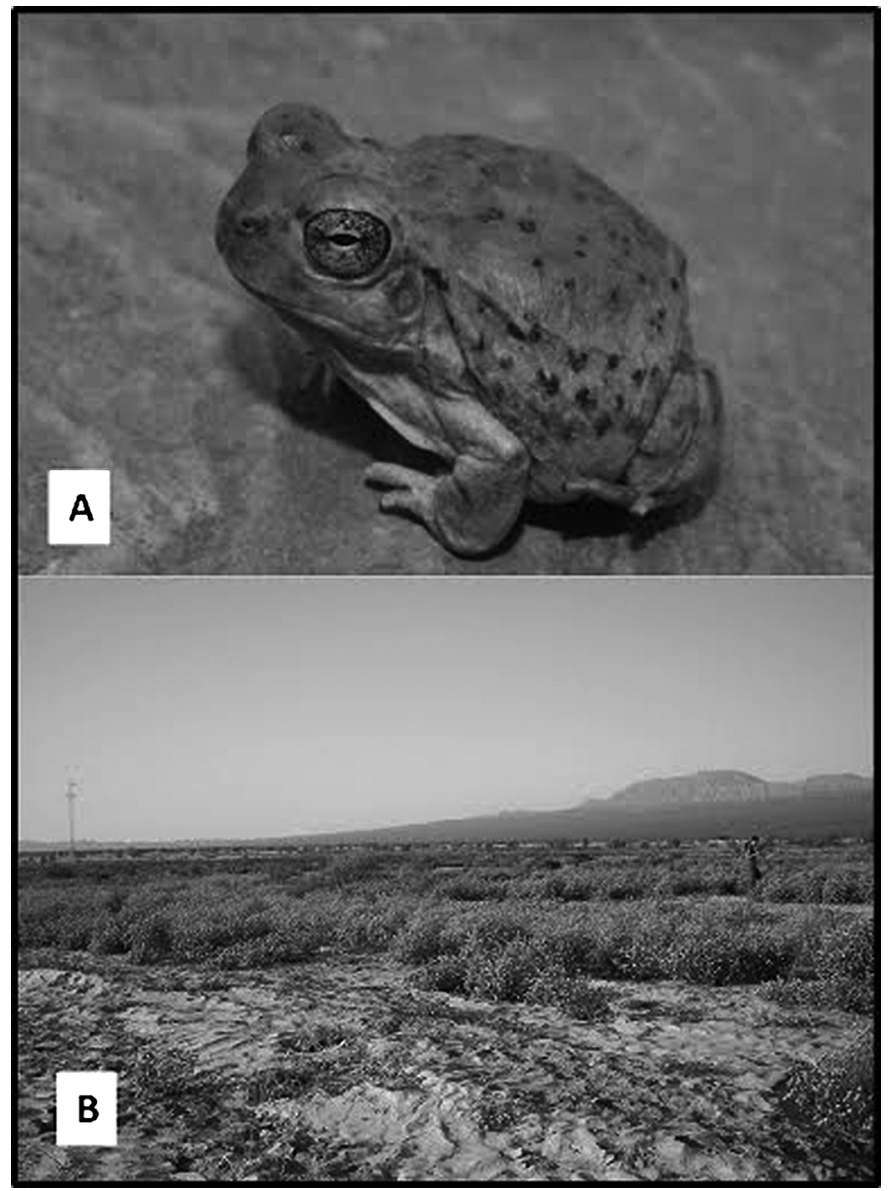

FIGURE 3. A. Adult male of Pleurodema nebulosum from Matagusanos. B. Panoramic view of type locality.

\section{Key to Neotropical species of Aplectana}

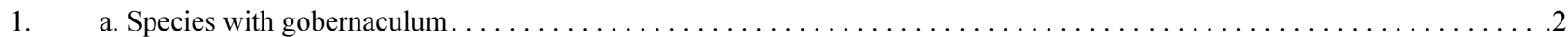

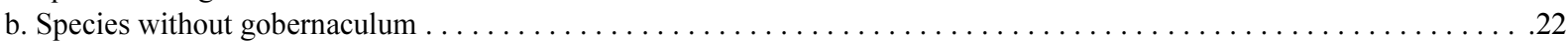

2. a. Numerous caudal papillae, variable in number and distribution and indistinguishable from somatic papillae. Anura and Squamata .................................... macintoshii (Steward, 1914) Travassos, 1931

b. Caudal papillae regularly distributed and distinguishable from somatic papillae $\ldots \ldots \ldots \ldots \ldots \ldots \ldots \ldots \ldots \ldots$

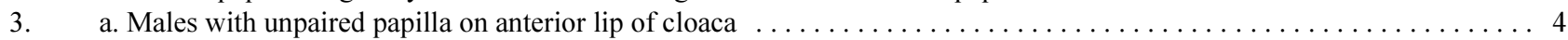

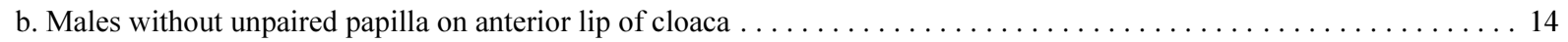

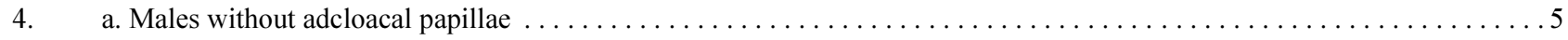

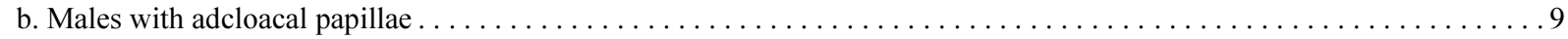

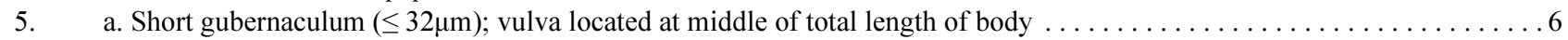

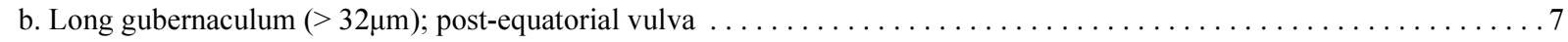

6. a. Gubernaculum very short $(12 \mu \mathrm{m})$; spicules less than $200 \mu \mathrm{m}$ with a basal process approximately one third of total length; two pairs of precloacal papillae and three pairs of postcloacal papillae. Anura A. vellardi Travassos, 1926

b. Gubernaculum longer than $12 \mu \mathrm{m}(32 \mu \mathrm{m})$; spicules longer than $200 \mu \mathrm{m}$ without basal process; eight pairs of precloacal papillae and eight pairs of postcloacal papillae. Male tail with short spike-like point. Squamata . ...................

A. raillieti Travassos, 1925

7. a. Four pair of precloacal papillae; large spicules $(>230 \mu \mathrm{m})$ with unequal distal projections, bluntly pointed, surrounded by a

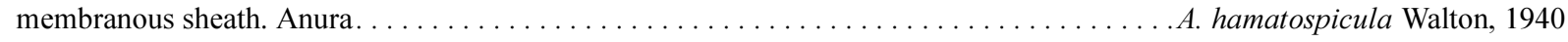
b. Eight pairs of precloacal papillae; five pairs of postcloacal papillae; spicules less than $230 \mu \mathrm{m}$ with blunt capitulum and sharply pointed distal extremity surrounded by transparent rounded sheath $\ldots \ldots \ldots \ldots \ldots \ldots \ldots \ldots \ldots$

8. a. Males and females with maximum length of 2.53 and $3.88 \mathrm{~mm}$, respectively (total length is approximately half of that of $A$. itzocanensis); spicules and gubernaculum short $(\leq 143 \mu \mathrm{m}$ and $\leq 63 \mu \mathrm{m}$, respectively); vulva with papillae. Anura . . . . . . .

A. incerta Caballero, 1949

b. Males and females with minimum length of 2.55 and $3.50 \mathrm{~mm}$, respectively (total length is approximately twice that of $A$. incerta); spicules and gubernaculum large $(>172 \mu \mathrm{m}$ and $>67 \mu \mathrm{m}$, respectively); six pairs of postcloacal papillae; vulva without 
a. Vulva with 2-3 mamelon-like protuberances; distal end of spicules covered by a prominent hook-shaped membrane approximately $40-50 \mu \mathrm{m}$ long and usually directed laterally. Anura . . . . . . . . . . A. hylambatis (Baylis, 1927) Travassos, 1931 b. Vulva without mamelon-like protuberances; spicules not covered by a hook-shaped membrane $\ldots \ldots \ldots \ldots \ldots$

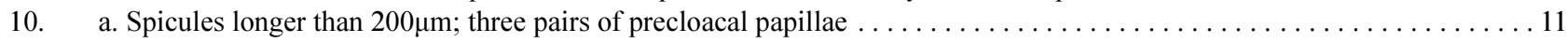
b. Spicules less than $200 \mu \mathrm{m}$; more of three pairs of precloacal papillae; five pairs of postcloacal papillae $\ldots \ldots \ldots \ldots 12$

11. a. Vulva non-salient; gubernaculum short $(53 \mu \mathrm{m})$; spicules with sharply pointed distal extremity and blunt proximal extremity thickened on dorsal side; five pairs of subventral muscle cells located anterior to cloaca. Anura. . .

A. paraelenae Baker and Vaucher, 1986 b. Vulva weakly protruding; gubernaculum longer than $53 \mu \mathrm{m}(70-95 \mu \mathrm{m})$; spicules prominent, curved ventrally at midportion, with blunt capitulum and sharply pointed distal extremity; twelve to thirteen pairs of slender subventral muscle cells located anterior to cloaca. Anura.

A. travassosi (Gomes and Motta, 1967) Baker, 1980

12. a. Eight pairs of precloacal papillae; only one pair of adcloacal papillae; spicules with markedly large proximal knob and tapering distally into finely attenuated point; lateral alae in males extending beyond cloaca. Anura

A. elenae Baker and Vaucher, 1986 b. Precloacal papillae less than 7 pairs; two-four pairs of adcloacal papillae; spicules simple; lateral alae in males ending before

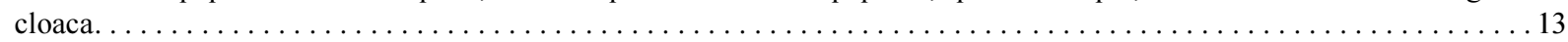

13. a. Four pairs of precloacal papillae; spicules less than $85 \mu \mathrm{m}(57-63 \mu \mathrm{m})$ without capitulum; vulva non-salient. Squamata. ... . . . . . . . . . . . . . . . . . . . . . . . . . . . . . . . . . . . Albae Adamson and Baccam, 1988 b. Six or seven pair of precloacal papillae; spicules longer than $85 \mu \mathrm{m}$ with capitulum at proximal end; vulva slightly salient. Anura. Aplectana nebulosa sp. nov.

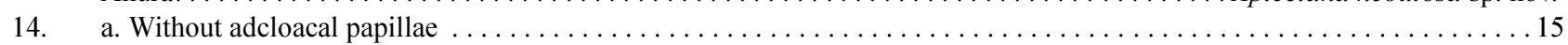

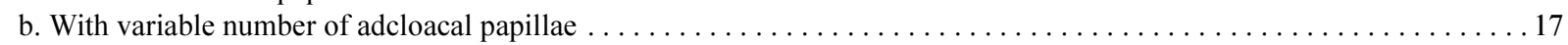

15. a. Gubernaculum very short $(10 \mu \mathrm{m})$, crescent-shaped with concavity towards the proximal edge, and a small appendix on the distal convex edge; only one pair of postcloacal papillae; tail of male conical and sharply-pointed; vulva medial; tail of female very long $(510 \mu \mathrm{m})$. Anura . . . . . . . . . micropenis Travassos, 1925 b. Gubernaculum longer than $10 \mu \mathrm{m}$ without the abovementioned characteristics; more of one pair of postcloacal papillae;

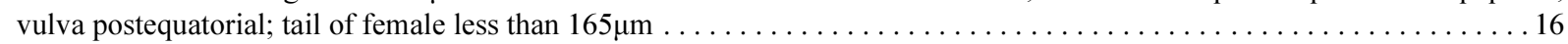

16. a. Long spicules $(450 \mu \mathrm{m})$; three pair of precloacal papillae and five pair of postcloacal papillae; vulva non salient. Gymno-

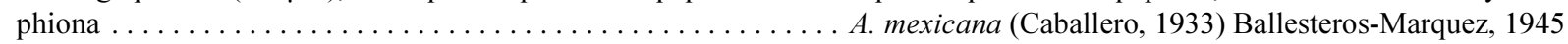
b. Spicules less than $79 \mu \mathrm{m}$; nine pairs of precloacal papillae and three pairs of postcloacal papillae; vulva weakly protruding. Squamata . . . . . . . . . . . . . . . . . . . . . . . . . . . . . herediaensis Bursey, Goldberg and Telford, 2006

17. a. Spicules and gubernaculum very long $(720 \mu \mathrm{m}$ and $110 \mu \mathrm{m}$, respectively); female with conical posterior end with three small

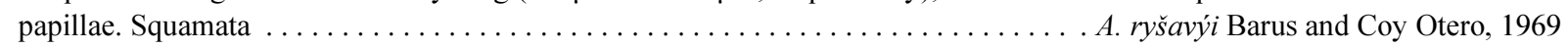
b. Spicules and gubernaculum less than $720 \mu \mathrm{m}$ and $110 \mu \mathrm{m}$, respectively; posterior end of females without papillae $\ldots \ldots 18$

18. a. Numerous pairs of precloacal papillae ( \pm 18 pairs) and 7 pairs of postcloacal papillae; female with posterior end of body rounded, ending in evident slender filament. Anura . . . . . . . . . . . . . . . . . . . . A. lopesi Silva, 1955 b. Fewer precloacal papillae ( 9 pairs or less) and less than 7 pairs of postcloacal papillae; posterior end of females without slen-

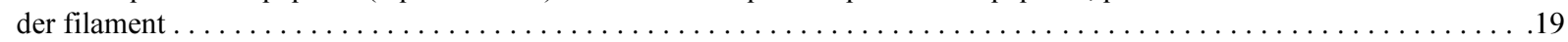

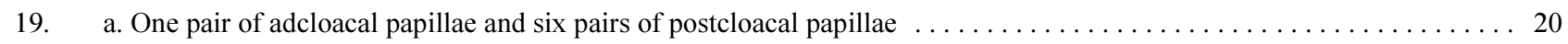
b. More than one pair of adcloacal papillae and less than 6 pairs of postcloacal papillae $\ldots \ldots \ldots \ldots \ldots \ldots \ldots \ldots$

20. a. Vulva with 3 mamelon-like protuberances; spicules with blunt capitulum and distal extremity covered by a hook-shaped membrane; eight pairs of precloacal papillae; spicules large $(>250 \mu \mathrm{m})$. Anura.

A. adaechevarriae Ramallo, Bursey and Goldberg, 2008 b. Vulva non-salient without mamelon-like protuberances; spicules without capitulum and without hook-shaped membrane; 9 pairs of precloacal papillae. Squamata . . . . . . . . . . . . . . A. tucumanensis Ramallo, Bursey and Goldberg, 2008

21. a. Two pairs of precloacal papillae; gubernaculum and spicules long $(120-150 \mu \mathrm{m}$ and $320-520 \mu \mathrm{m}$, respectively); spicules alate and with pointed distal extremity, not bifurcated; 3 toothlike projections in oesophagus. Caudata

A. uaehi Falcon-Ordaz, Monks, Pulido-Flores and Rodriguez-Amador, 2014* b. Five pairs of precloacal papillae; gubernaculum and spicules short $(71 \mu \mathrm{m}$ and $227-234 \mu \mathrm{m}$, respectively); spicules not alate and with distal bifurcated extremity; without toothlike projections in oesophagus. Anura

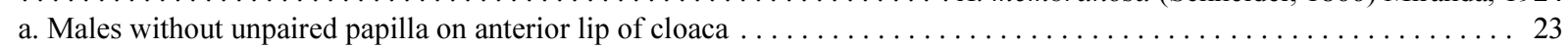

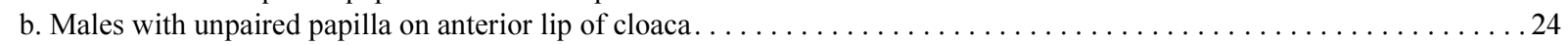

23. a. Twelve pairs of precloacal papillae, without adcloacal papillae, six pairs of postcloacal papillae; tail long, slender and sharply pointed in both sexes; in males, the lateral alae extend beyond the cloaca where tail begins to taper. Anura. . . .

A. chilensis Lent and Freitas, 1948 b. Six pairs of precloacal papillae, one pair of adcloacal papillae, four pairs of postcloacal papillae; tail long, slender and

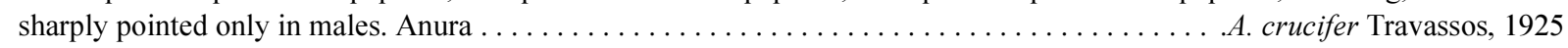

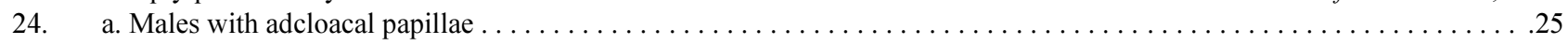

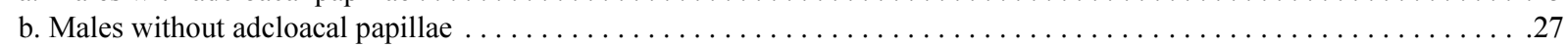

25. a. Numerous pairs of precloacal papillae (>14 pairs); one pair of adcloacal papillae; spicules longer than $300 \mu \mathrm{m} \ldots \ldots \ldots 26$ b. Seven pairs of precloacal papillae; two pairs of adcloacal papillae; spicules shorter than $300 \mu \mathrm{m}(130-136 \mu \mathrm{m})$; tail long, slender and sharply pointed in both sexes. Anura. . . . . . . . . . . . . . . . . . A. meridionalis Lent and Freitas, 1948 
26. a. Fourteen pairs of precloacal papillae in two longitudinal rows; spicules less than $400 \mu \mathrm{m}(322-364 \mu \mathrm{m})$; tail long, slender and sharply pointed in both sexes; distance from anus to posterior end in females longer than $650 \mu \mathrm{m}(690-952 \mu \mathrm{m})$. Anura. . . . . $\ldots \ldots \ldots \ldots \ldots \ldots \ldots \ldots \ldots \ldots \ldots \ldots \ldots \ldots \ldots \ldots \ldots \ldots \ldots \ldots \ldots \ldots \ldots \ldots \ldots \ldots \ldots \ldots \ldots$ artigasi Puga and Torres, 1997 b. Variable number of precloacal papillae in four longitudinal rows; spicules $400 \mu \mathrm{m}$ long; distance from anus to posterior end in females less than $650 \mu \mathrm{m}(332-380 \mu \mathrm{m})$. Squamata . . . . . . . . . . . . . . . . papillifera (Araujo, 1977) Baker, 1980

27. a. Numerous pairs of precloacal papillae ( $>20$ pairs); spicules longer than $130 \mu \mathrm{m}$; posterior end in females tapering abruptly in proximal third, becoming spike-like distal portion. Anura . . . . . . . . . . . . . . . . . . . . . A. delirae (Fabio, 1971) b. Only one pair of precloacal papillae; spicules less than $130 \mu \mathrm{m}$; tail of female conical. Anura. . . . . . . . . . . . . A. tarija Ramallo, Bursey and Goldberg, 2007 * This record was made in a restricted area of the Mexican Transition zone between the Nearctic and Neotropical Regions.

\section{Discussion}

Up to the present, seven species of Aplectana have been reported from Argentina: A. adaechevarriae, A. delirae, A. hylambatis, A. meridionalis, A. nebulosa sp. nov., A. tarija, and A. tucumanensis. Only A. tucumanensis was found in Amphisbaena bolivica Mertens, 1929, an amphisbaenid (Squamata) host (Ramallo et al., 2008a), while the other species were found in leptodactylid and bufonid anurans. Three of these species were first described from amphibians collected in Argentina: A. adachevarriae was described from Rhinella granulosa (Müller and Hellmich, 1936) and R. schneideri (Werner, 1894) (Ramallo et al., 2008b), A. tarija from R. arenarum (Hensel, 1867) (Ramallo et al., 2007), and the new species, A. nebulosa sp. nov. was described from P. nebulosum. All these species have a limited geographical distribution and have only been found in their respective type-host species. The rest of the abovementioned species, A. hylambatis, A. delirae, and A. meridionalis, were described from amphibian hosts from different countries that have wider geographical distributions. Aplectana delirae was described from Rhinella ornata (Spix, 1824) (= Bufo crucifer) from Rio de Janeiro, Brazil (Fabio, 1971), and was also found in Argentina in Rhinella major, Leptodactylus chaquensis Cei, 1950, and L. elenae Heyer, 1978 (González and Hamann, 2006; 2016; Schaefer et al., 2006), Aplectana meridionalis was described from Odontophrynus americanus (Duméril and Bibron, 1841) (= Ceratophrys americana) from Montevideo, Uruguay (Lent and Freitas, 1948), and reported in Argentina from Pleurodema borellii (Baker, 1980). Finally, A. hylambatis was originally described from Leptopelis aubryi (Duméril, 1856) from Guinea, Africa (see Baker and Vaucher, 1986), and recorded in Argentina in several hosts: Rhinella achalensis (Cei, 1972) (= Bufo achalensis), R. arenarum, R. major, Leptodactylus latinasus Jiménez de la Espada, 1875, L. chaquensis, L. bufonius Boulenger, 1894, Physalaemus santafecinus Barrio, 1965, and Trachycephalus venulosus (Linnaeus, 1758) (González and Hamann, 2015; 2016; Hamann and González, 2015; Draghi et al., 2015).

The frog genus Pleurodema is distributed from Panama throughout South America, reaching southern Chile and Argentina, and is currently represented by fifteen species (Faivovich et al., 2012). Helminth parasites in anurans of this genus have been reported from four countries: the nematodes Aplectana chilensis Lent and Freitas, 1948, Rhabdias sp., and Oswaldocruzia sp. were found in Pleurodema thaul from Chile (Benavidez et al., 1996), the nematodes Aplectana hylambatis and Oxyascaris sp. were found in P. marmoratum from Peru (Sarmiento et al., 1999), the nematodes Raillietnema spectans Gomes, 1964 and Oxyascaris oxyascaris Travassos, 1920 (= Oxyascaris necopinus Freitas, 1958; see Fabio, 1980), and plerocercoid larvae of the family Proteocephalidae have been found in P. diplolister Peters, 1870 from Brazil (Freitas, 1958; Fabio, 1980; Teles et al., 2015), and the monogenean Polystoma borellii Combes and Laurent, 1974, and the nematode Aplectana meridionalis Lent and Freitas, 1948, found in P. borelli (Peracca, 1895) from Argentina (Baker, 1980; Combes and Laurent, 1974). Also, the acanthocephalan, Pseudoacanthocephalus lutzi (Hamann, 1891) Arredondo and Gil de Pertierra, 2009 (locality not reported), was found in P. bibroni Tschudi, 1838 (Cordero, 1933).

This study represents the first report of nematode parasites in P. nebulosum, and Aplectana nebulosa sp. nov. represents the 28 species assigned to the genus from the Neotropical Realm. More work will be required to determine if the new species is a common component of the helminth community of amphibians from deserts.

\section{Acknowledgments}

We would like to thank to Lorena B. Quiroga for field support and critical reading of the manuscript. We thank the 
provincial fauna office of San Juan for permission (SA y DS no 1300-4736-2011) to carry out this research. This research was partially supported by CICITCA-UNSJ-F1003 to EAS.

\section{References}

Baker, M.R. \& Vaucher, C. (1986) Parasitic helminths from Paraguay XII: Aplectana Raillet and Henry, 1916 (Nematoda: Cosmocercoidea) from frogs. Revue Suisse de Zoologie, 93, 607-616. https://doi.org/10.5962/bhl.part.79500

Baker, M.R. (1980) Revision of Old World species of the genus Aplectana Raillet and Henry, 1916 (Nematoda, Cosmocercidae). Bulletin du Museum National d'Histoire Naturelle, Series 4, Sect. A, 2, 955-998.

Baker, M.R. (1987) Synopsis of the Nematoda parasitic in amphibians and reptiles. Memorial University of Newfoundland. Occasional papers in Biology, 11, 1-325.

Benavides, M., Ortiz, J.C. \& Jerez, V. (1996) Primer registro parasitológico en Pleurodema thaul Lesson 1826 (Anura, Leptodactylidae). Parasitología al Día, 20 (1/2), 59-62.

Bursey, C.R., Goldberg, S.R. \& Kraus, F. (2011) New Species of Aplectana (Nematoda: Cosmocercidae) in Sphenomorphus pratti from Papua New Guinea. Journal of Parasitology, 97 (4), 654-660. https://doi.org/10.1645/ge-2720.1

Cabrera, A.L. (1976) Regiones fitogeográficas de la República Argentina. In: ACME (Ed.), Enciclopedia Argentina de Agricultura y Jardinería. Editorial A.C.M.E., Buenos Aires, pp. 1-85

Combes, C. \& Laurent, R.F. (1974) Polystoma borelli n. sp. (Monogenea, Polystomatidae) parasites de Pleurodema borelli (Anura, Leptodactylidae) en Republique Argentine. Acta Zoologica Lilloana, 31, 57-64.

Cordero, E.H. (1933) Sur quelques acanthocéphales de l'Amérique méridionale, I. Annales de Parastologie (Paris), 11, 271279.

Draghi, R., Lunaschi, L.I. \& Drago, F.B. (2015) First report of helminth parasitizing Trachycephalus typhonius (Anura: Hylidae) from northeastern Argentina. Revista Mexicana de Biodiversidad, 86, 255-261. https://doi.org/10.7550/rmb.47677

Fabio, S.P. (1971) Sobre uma nova espécie do gênero Neyraplectana Ballesteros Marquez, 1945 (Nematoda, Cosmocercidae). Atas da Sociedade de Biologia do Rio de Janeiro, 15 (1), 11-13.

Fabio, S.P. (1980) Consideraçoes sobre o gênero Oxyascaris Travassos, 1920 (Nematoda, Subuloroidea). Revista Brasileira de Biología, 40 (3), 629-634.

Faivovich, J., Ferraro, D.P., Basso, N.G., Haddad, C.F.D., Rodrigues, M.T., Wheeler, W.C. \& Lavilla, E.O. (2012) A phylogenetic analysis of Pleurodema (Anura: Leptodactylidae: Leiuperinae) based on mitochondrial and nuclear gene sequences, with comments on the evolution of anuran foam nests. Cladistics, 1, 1-23. https://doi.org/10.1111/j.1096-0031.2012.00406.x

Ferraro, D.P. \& Casagranda, M.D. (2009) Geographic distribution of the genus Pleurodema in Argentina (Anura: Leiuperidae). Zootaxa, 2024, 33-55.

Freitas, J.F. (1958) Estudos sobre "Oxyascarididae" (Travassos, 1920) (Nematoda, Subuluroidea). Memórias do Instituto Oswaldo Cruz, 56 (2), 489-515. https://doi.org/10.1590/s0074-02761958000200008

Frost, D. R. (2016) Amphibian Species of the World: an Online Reference. Version 6.0. Electronic Database. American Museum of Natural History, New York, USA. Available from: http://research.amnh.org/herpetology/amphibia/index.html (accessed 3 April 2016)

Gibbons, L.M. (2010) Keys to the nematode parasites of vertebrates. Supplementary Volume. CAB International and Natural History Museum, London, $146 \mathrm{pp}$.

Goldberg, S.R., Bursey, C.R. \& Morando, M. (2004). Metazoan endoparasites of 12 species of lizard from Argentina. Comparative Parasitology, 71 (2), 208-214. https://doi.org/10.1654/4089

González, C.E. \& Hamann, M.I. (2006) Nematodes parásitos de Chaunus granulosus major (Müller \& Hellmich, 1936) (Anura: Bufonidae) en Corrientes, Argentina. Cuadernos de Herpetología, 20 (1), $43-49$.

González, C.E. \& Hamann, M.I. (2015) Checklist of nematode parasites of amphibians from Argentina. Zootaxa, 3980 (4), 451-476. https://doi.org/10.11646/zootaxa.3980.4.1

González, C.E. \& Hamann, M.I. (2016) Nematode parasites of Leptodactylus elenae and Leptodactylus podicipinus (Anura: Leptodactylidae) from Corrientes, Argentina. Comparative Parasitology, 83 (1), 117-121. https://doi.org/10.1654/1525-2647-83.1.117

González, C.E., Quiroga, L.B. \& Sanabria, E.A. (2014) First survey of nematode parasites in introduced American bullfrogs (Lithobates catesbeianus) in Argentina. Comparative Parasitology, 81 (2), 284-287. https://doi.org/10.1654/4700.1

González, C.E., Quiroga, L.B., Moreno, D. \& Sanabria, E.A. (2013b) Primer registro de Aplectana hylambatis (Nematoda, 
Cosmocercidae) para anfibios de la Provincia de San Juan. Cuadernos de Herpetología, 27 (2), 155-159.

González, C.E., Sanabria, E.A. \& Quiroga, L.B. (2013a) Falcaustra sanjuanensis sp. nov. (Nematoda: Kathlaniidae) from Odontophrynus cf. barrioi (Anura: Cycloramphidae) from Argentina. Acta Parasitologica, 58 (1), 119-125. https://doi.org/10.2478/s11686-013-0105-2

Hamann, M.I. \& González, C.E. (2015) Helminth parasites in the toad Rhinella major (Bufonidae) from Chaco region, Argentina. Acta Herpetologica, 10 (2), 93-101. https://doi.org/10.13128/Acta_Herpetol-16150

Lent, H. \& Teixeira de Freitas, J.F. (1948) Uma coleçao de Nematódeos, parasitos de vertebrados, do Museu de Historia Natural de Montevideo. Memórias do Instituto Oswaldo Cruz, 46, 1-71. https://doi.org/10.1590/s0074-02761948000100001

Ramallo, G. \& Díaz, F. (1998) Physaloptera lutzi (Nematoda, Physalopteridae) parasite of Liolaemus (Iguania, Tropiduridae) from northwestern Argentina. Boletín chileno de parasitologia, 53, 19-22.

Ramallo, G., Bursey C.R., Goldberg, S.R., Castillo, G. \& Acosta, J.C. (2016b) Leptodactylus latrans (Creole Frog). Endoparasites. Herpetology Review, 47, 279-280.

Ramallo, G., Bursey, C.R. \& Goldberg, S.R. (2002a) Spauligodon loboi n. sp. (Nematoda: Pharyngodonidae) parasite of Liolaemus spp. (Iguania: Liolaemidae) from Northwestern Argentina. Journal of Parasitology, 88 (2), 370-374. https://doi.org/10.2307/3285591

Ramallo, G., Bursey, C.R. \& Goldberg, S.R. (2002b) Parapharyngodon riojensis n. sp. (Nematoda: Pharyngodonidae) from the lizard Phymaturus punae (Squamata: Iguania: Liolaemidae) from Northwestern Argentina. Journal of Parasitology, 88 (5), 979-982. https://doi.org/10.2307/3285541

Ramallo, G., Bursey, C.R. \& Goldberg, S.R. (2007) Two new species of Cosmocercids (Ascaridida) in the toad Chaunus arenarum (Anura: Bufonidae) from Argentina. Journal of Parasitology, 93 (4), 910-916. https://doi.org/10.1645/ge-1131r.1

Ramallo, G., Bursey, C.R. \& Goldberg, S.R. (2008a) A new species of Cosmocercidae (Ascaridida) in the worm lizard, Amphisbaena bolivica (Squamata: Amphisbaenidae), from Argentina. Journal of Parasitology, 94 (6), 1361-1363. https://doi.org/10.1645/ge-1415.1

Ramallo, G., Bursey, C.R. \& Goldberg, S.R. (2008b) New species of Aplectana (Ascaridida: Cosmocercidae) in the toads, Rhinella granulosa and Rhinella schneideri (Anura: Bufonidae) from northern Argentina. Journal of Parasitology, 94 (6), 1357-1360. https://doi.org/10.1645/ge-1422.1

Ramallo, G., Bursey, C.R., Castillo, G. \& Acosta, J.C. (2016a) New species of Parapharyngodon (Nematoda: Pharyngodonidae) in Phymaturus spp. (Iguania: Liolaemidae) from Argentina. Acta Parasitologica, 61 (3), 461-465. https://doi.org/10.1515/ap-2016-0062

Ramallo, G., Goldberg, S., Bursey, C., Castillo, G. \& Acosta, J.C. (2017) Thubunaea eleodori sp. nov. (Nematoda: Physalopteridae) from Liolaemus eleodori (Sauria: Liolaemidae) from Argentina. Parasitology Research, 116 (1), $293-$ 297. https://doi.org/10.1007/s00436-016-5290-0

Sarmiento, L., Tantaleán, M. \& Huiza, A. (1999) Nemátodos parásitos del hombre y de los animales en el Perú. Revista peruana de parasitología, 14, 9-65.

Schaefer, E.F., Hamann, M.I., Kehr, A.I., González, C.E. \& Duré, M.I. (2006) Trophic, reproductive and parasitological aspects of the ecology of Leptodactylus chaquensis (Anura: Leptodactylidae) in Argentina. Herpetological Journal, 16, $387-394$.

Teles, D.A., Sousa, J.G.G., Teixeira, A.A.M., Silva, M.C., Oliveira, R.H., Silva, M.R.M. \& Ávila, R.W. (2015) Helminths of the frog Pleurodema diplolister (Anura, Leiuperidae) from the Caatingain Pernambuco State, Northeast Brazil. Brazilian Journal of Biology, 75, 251-253. https://doi.org/10.1590/1519-6984.08513

Warner, T.T. (2004) Desert Meteorology. Cambridge University Press, New York, 268 b/w illus., 11 colour illus., 30 tables. 